\title{
Rethinking niche tourism: The example of backpacking
}

\author{
Greg Richards
}

Tilburg University in the Netherlands

\begin{abstract}
This conceptual paper re-evaluates the concept of niches in tourism markets. As many regions are now attempting to address niche markets in tourism as a development strategy, understanding of the dynamics of niche markets is crucial. Current approaches are often limited to seeing niche markets as simple subsectors of larger consumer markets. We argue for a broader view of market niches as forms of social rituals involving both consumers and producers with a mutual focus of attention. Based on the work of Randall Collins we examine how interaction rituals are produced and maintained, and how these are also reflected in niche markets, such as backpacking. We illustrate the how backpacking produces a mutual focus of attention and boundaries to outsiders, helping to sustain the niche over the longer term. This analysis has implications for producers hoping to tap into niche markets, as they too need to become part of the niche community.
\end{abstract}

Keywords: Niche markets, consumption, production, backpacking, tourism.

Paper type: Research article

Received: 26.10.2020.

Accepted: 26.11.2021.

DOI: $10.2478 / \mathrm{crdj}-2021-0004$

\section{Introduction}

Most thinking about niches is not surprisingly based on marketing theory - the niche is specialised space in the market where a firm can escape direct competition or exploit its own special competence. Viewed from a consumer perspective, there is a tendency to link niches with specific special interests, which constitute a coherent market to be served. There has been increasing attention for niche markets within tourism and other consumer markets, as these are also seen as growing in importance in increasingly fragmented markets (Novelli, 2005).

Relatively little attention is paid, however, to how niches are identified, develop and are consolidated. This paper provides some initial theoretical work on the development of tourism niches, drawing on some key facets of contemporary social development in the experience economy and the network society. It draws on the example of backpacking as a travel niche in which the maintenance of niche identity is supported by the development of 'Interaction Ritual Chains'.

A consideration of niche markets is important to regional development because increasing competition is forcing regions to specialise, as exemplified in the European Commission (2010) initiative towards 'smart specialisation'. Service industries, such as tourism, provide 
an important and flexible source of specialisation, and many regional development strategies have been based on identifying and developing suitable tourism niche markets.

For example, Michael (2003) considers the development of 'micro-clusters' aimed at different tourism niches such as book towns, wine tourism clusters, fishing, and nature tourism, which aim to generate comparative advantage. Other authors have examined the development of niche markets such as golf tourism (Tassiopoulos \& Haydam, 2008), arts tourism (Lim \& Bendle, 2012), or diaspora tourism (Newland, K., \& Taylor, C. (2010). The development of niche markets in tourism is most often pursued from a marketing perspective, in which niches are seen as subsectors of larger markets. This paper presents a view of niche markets as relational social fields, in which relational capital becomes an important driver of behaviour, alongside more traditional economic exchange approaches.

\section{Niches and social theory}

The term 'niche tourism' derives largely from marketing theory and the concept of niche marketing, which in turn leans on the concept of an ecological niche (Novelli, 2005). In ecology, the niche characterizes the position of a species within an ecosystem, which is a unique combination of a physical habitat and how a species has adapted to life in that habitat. As Dalgic and Leeuw (1994:40) argue:

Some marketers have long advocated the use of ecology or biological theory in marketing in order to study markets. A relationship may be drawn between the ecological niche and the market niche... In both cases, organisms and organizations live in their immediate physical environment and are able to continue their life forms in a changing environment.

The implication of this is that suppliers escape competition in mass markets by seeking a specific niche which is better suited to them than to their competitors. Niche marketing is therefore 'a process of offering the products that are differentiated and do not have many alternatives to an individual customer or a narrowly defined group of customers with similar characteristics or needs' (Sert, 2017, p. 16). In rapidly fragmenting consumer markets, according to Dalgic and Leeuw (1994:44), companies need to be flexible and develop differentiated products to meet the needs of different niches: 'In niche marketing the focus is on the customer and on profit; niche marketers specialize in serving marketing niches. Instead of pursuing the whole market (mass marketing), or large segments of the market, these firms target segments within segments or, for the sake of simplicity, niches.' The same logic can be extended to the marketing of tourism, both in terms of products and destinations. For example, many regions have developed niche tourism products in order to compete more effectively in the face of globalization. Niche tourism, because it is often based on special interests of the consumers, is seen as a useful tool for regions to strengthen their tourism products and market profile through specialisation.

Seen from the supply side, companies simply have to identify different market niches and meet the needs of these markets. However, this begs the question of how niches actually arise and how suppliers can identify and interact with them. In ecology, niches are created through evolution and natural selection. In a social system, however, a different approach may be required to guide our thinking on niches.

In social systems, the differentiation inherent in the creation of niches can be related to the process of distinction. Classic work on social distinction (Bourdieu, 1984), for example, emphasised the role of cultural capital and symbolic consumption in maintaining difference. For Bourdieu, social classes could develop and maintain their distinction through the acquisition of cultural capital, in his eyes related to the development of 'taste' and the consumption of high culture. In recent years this model has been problematised by the de- 
differentiation of 'high' and 'popular' culture, and the emergence of 'omnivorous' patterns of consumption (Peterson, 2003). More recent work in sociology has emphasised the growth of eclectic consumption patterns (Bellevance, 2008), which have disarticulated the previously assumed relationships between specific social groups and specific products. This effectively means that although one might be able to identify a niche as a group of consumers who consume a particular product, it is more difficult to see the market niche as a direct corollary of the ecological niche, since there is no longer one single type of consumer who consumes one single type of product.

In this more complex field of consumption, some social scientists have suggested that instead of analysing the consumption of social groups (either in terms of class or market segments), it may be more fruitful to study the particular practices that people undertake, and in particular how meaning is formed and communities of interested created through such practices.

Pantzar and Shove (2005) argue that a focus on practices produces a new set of research questions, which we could certainly apply to the study of niches:

- What it means to participate

- How enthusiasms develop and flourish

- The demands that practices make of those who follow them

- Specific mechanisms of attraction and defection

- The relationship between individual practitioners and the unfolding entity of the practice

In a practice approach to consumption, "the concept of "the consumer", a figure who has bewitched political and social scientists as well as economists, evaporates. Instead the key focal points become the organization of the practice and the moments of consumption enjoined. Persons confront moments of consumption neither as sovereign choosers nor as dupes. (Warde, 2005). Rather than simply consuming what is offered in a particular 'market niche', the consumer is actively involved in forming a specific niche through their consumption practices.

At the same time as the distinctions between groups of consumers is lessening, the boundaries between producers and consumers are also becoming more vague. Consumers are increasingly involved in the development and design of leisure products. Rather than just major corporations undertaking research and development to create new products and services, these may be initiated by users, sometimes for their own pleasure or satisfaction, sometimes as small-scale entrepreneurs, and sometimes in conjunction with larger producers.

The integration of consumption and production is also made explicit in the concept of 'cocreation' (Binkhorst and den Dekker, 2009). This involves 'consumers' and 'producers' coming together to jointly create value. In the narrow conception of co-creation in the marketing literature this means 'firms' building relationships with 'customers' in order to better meet their needs. In the wider social field, however, it is becoming increasingly obvious that it actually involves the breaking down of barriers between production and consumption in an act of 'prosumption'. In the leisure field, for example, there is increasing identification of 'lifestyle entrepreneurs' who want to support consumption of a specific activity by starting up a business in that field (Peters et al., 2009). The motivations for different parties to engage in these systems of co-creation is also slightly different from traditional markets. Of course, there is money to be made, but in contrast to traditional entrepreneurs, the new lifestyle entrepreneurs or lead users are often more concerned 
about reputational or relational capital and their position in wider user networks (Castelfranchi et al., 2006).

When the barriers between production and consumption begin to break down, so do traditional power relationships. It is no longer just the major producers who control markets, but very often the influential users (or 'lead users') who innovate and develop products in the first place (Walder et al., 2006). Such markets are dominated not by important suppliers, but by reputation and position in a social field of co-creation.

In the contemporary prosumption, co-creation marketplace, therefore, traditional thinking about niches may need to be reconsidered. It is no longer just the producer who identifies a suitable niche market to escape the cold wind of mass market competition: niches are formed and developed by producers and consumers acting in a symbiotic manner to gain mutual benefit from specific practices. The question of how niches arise, are maintained and eventually disappear is therefore closely related to the recruitment and retention of actors in those practices. Recent research on the development of social practices has provided new potential ways of looking at niches as a specific form of social practice: the ritual interaction chain (Bargeman and Richards, 2020).

\section{Interaction Ritual Chains}

There has been increasing attention in the tourism, leisure and events fields for the work of Randall Collins (2004), a sociologist who has been concerned with the analysis of ritual behaviour (Bargeman and Richards, 2020; Richards, 2014; Simons, 2019). Collins argues that much social behaviour is organised around 'Interaction Ritual Chains', which Collins sees as "a theory of individuals' motivation based on where they are located at any moment in time .....in their market of possible social relationships" (p. xiv). Participation in Ritual Interaction Chains generates what Collins calls 'Emotional Energy', or 'the master motive across all institutional arenas'. People are attracted to particular rituals or practices because of the Emotional Energy they can gain from them. Collins identifies a number of key features of such practices:

1. Two or more people in co-presence: bodily assembled and, through neurological feedback loops, able to charge up a situation with excitement and significance.

2. A boundary that demarcates insiders from outsiders, lending participants a privileged sense of inclusiveness

3. All parties to the encounter have a common focus of attention

4. Participants share "a common mood or emotional experience"

When the interaction ritual is performed successfully, this produces a number of outcomes:

1. Individuals feel solidarity with one another; they imagine themselves to be members of a common undertaking.

2. They are infused with emotional energy, a feeling of exhilaration, achievement and enthusiasm which induces initiative.

3. IR membership generates collective symbols that are defended and reinforced.

4. Violations of these symbols provoke righteous indignation towards, and sanctions against, those guilty of transgression. 
These characteristics of IRCs closely match the requirements of a niche: there is a clear distinction between the niche and other markets, provided by the boundary to outsiders. There is a common interest or focus of attention that binds members of the niche together. Most importantly, Collins provides a common motivation for being part of a niche: the mechanism of Emotional Energy (EE). The production of EE through the ritual ensures that people will tend to stay within the ritual, or niche, because they seek to repeat a successful international ritual that has generated excitement and enthusiasm. In this way, participants in the niche construct a chain of ritual interactions, and repetition of niche-related activities. Rituals also involve the production of what Maclntyre (2007) terms internal goods, or rewards that can only be attained through subordination to, and immersion in, the practice itself. This idea has close links with the Collins' idea of EE, but Maclntyre also emphasises the fact that ritual behaviour generates external goods - the resources necessary to keep the ritual going. In this sense, rituals or niches not only need to support the internal focus, or interest that supports the practice, but they also need to generate the resources, including economic resources, that will sustain the ritual over the longer term.

Although Collins emphasises the importance of physical co-presence in IRC, one can also imagine similar processes working in the virtual world as well. Simons (2019) has recently argued that interaction rituals can combine offline and online elements, with the physical co-presence of the ritual being extended through interaction via social media and other virtual means after the physical event. This mirrors observations about niche tourism markets such as Street Art Tourism, where hybrid experiences mixing physical artworks and festivals with digital media (Campos and Sequeira, 2020).

Seen as a process of interaction, niches not so much as a market to be supplied, but as a social space in which producers and consumers come together (increasingly as cocreators) to identify, develop, symbolize and profligate specific social practices. To illustrate how such processes work in tourism and leisure, I want to consider the example of the development of the backpacker tourism niche.

\section{The backpacking niche}

Backpacker tourism arguably emerged in the 1960s and 1970s as the antithesis of a market: counter cultural 'drifters' began to arrive in far flung corners of the world in search of peace, paradise (and often) drugs (Richards and Wilson, 2004). Their 'free' lifestyle of these 'lead users' eventually began to attract the attention of others wanting to emulate the lifestyle, even if just for a short while. This lead not just to an increase in demand, but to the creation of a backpacker 'scene', held together by specific rituals and patterns of behaviour (Welk, 2004: Noy, 2004). What has given coherence to the niche is the feeling of community; people identifying with each other strongly enough to constitute a coherent group, and in turn distinguishing themselves from other groups. Backpacker ideology consists of a series of practices related to their travel (Pearce, 2007):

- To travel on a low budget

- To meet different people (especially other backpackers, but also locals)

- To be (or to feel) free, independent and open-minded

- To organise one's journey individually and independently

- To travel for as long as possible 
Through these practices, backpackers learn how to be 'anti-tourists', and these are also strategies for defending the niche, for fighting assimilation with mainstream tourism. The niche is therefore defined by the practices of the backpackers themselves.

Research by the World Youth Student Educational Travel Confederation (WYSE) indicates that backpacking has become even more of a niche as international travel has grown in recent decades. The latest edition of the New Horizons survey of youth travel (WYSE Travel Confederation, 2018) indicates that $13 \%$ identified themselves as 'backpackers', compared with $32 \%$ of youth travellers in 2002. Even though the market share of the backpacking niche has fallen dramatically, the total number of backpackers has fallen only slightly, from around 45 million in 2002 to 39 million in 2017. So the backpacking niche has shown a certain level of resilience in the face of a dramatic expansion of other types of travel, such as the rise of 'flashpackers' and 'digital nomads' in recent years (Richards, 2015).

Arguably, one of the reasons for the long-term survival of the backpacker has been the way in which backpacking has become a ritual for many people. It is not just a form of travel, but a way of life, and an identity (Currie, Campbell-Trant \& Seaton, 2011). The backpacker ritual is maintained through a number of strategies that serve to reinforce the Interaction Ritual Chain. As Zhang, Tucker, Morrison and Wu (2017) describe in their study of Chinese backpackers, the separation of the group from other travellers and everyday life is an important aspect of identity formation. This mirrors Collins' description of the Interaction Ritual Chain as having barriers to outsiders. In the case of backpackers this is often in reference to other tourists, and particularly 'mass tourists'. Zhang et al. Also underline the role of social interaction in maintaining the backpacker ritual, which is also facilitated through storytelling and narrative. In terms of their travel behaviour, the Chinese backpackers studied by Zhang et al. also emphasise 'getting off the beaten track', which further serves to separate the backpacker group and to increase social interaction within the group itself. As Currie et al. (2011) comment: "the social interaction within the backpacker community preserves and develops the meaning of symbols."

The roles of separation and boundaries to outsiders in the practice of backpacking are most evident in the backpacker enclaves in different parts of the world, where the co-presence of large numbers of backpackers makes their maintenance of ritual boundaries all the more evident. A great deal of effort is expended to emphasise the fact that backpackers are different from normal 'tourists' (and even in some cases 'travellers') (Richards and Wilson, 2004). There is a mutual focus of attention, whether it be directed to the Lonely Planet (the backpacker's 'bible') or the stories told by the backpackers themselves. Although the backpack itself is usually ignored in definitions of backpacking, it is clearly an important collective symbol that marks the backpacker niche. Among the practices that one might expect to be associated with the backpacker 'scene' are the trappings of poverty and an abandonment of symbols of western modernity (such as wearing a watch). Backpacking has also been closely linked to a 'rite of passage', which generates Emotional Energy through the achievement of 'communitas'. Backpackers themselves patrol the borders of the niche, keeping out the tourists as well as new undesirables such as the 'flashpacker' (Jarvis and Peel, 2010).

The development of enclaves proceeds through an 'enclave development cycle' in which the backpackers constantly shift their location to avoid other tourists as the enclave expands and becomes more well-known and accessible. This causes a constant shifting of backpacker locations globally. The New Horizons research (WYSE Travel Confederation, 2018) shows that backpackers themselves still tend to favour South East Asia, with Lao, Cambodia and Vietnam all having high proportions of backpacker visitors. It is interesting that in 2017 Lao was the top destination, while India, the number one backpacker destination in 2012 is longer such a heavy backpacker destination. Instead, a large proportion (48\%) of visitors to India now see themselves as 'travellers', and in another long- 
time backpacker favourite, Thailand, $44 \%$ of visitors style themselves as 'tourists'. Backpackers also remain important for spearheading the development of emerging destinations, such as Iran, Bolivia and Myanmar.

But it is not just the role of the consumer which is important: producers are also an integral part of the niche. A brief look at the backpacker market turns up countless examples of the co-creation of backpacking. The Lonely Planet Guides, once the essential accessory for any self-respecting backpacker, was produced by a former backpacker. The same applies to countless hostels, travel companies and information services. One of the key aspects of the backpacker experience which is mirrored by producers is the idea of backpacking as a communal, social experience. Hostels are designed to provide communal spaces in which this essential interaction can take place, and this is extended into cyberspace through backpacker chat rooms and forums.

It is clear that these processes reflect many of the elements that we observe in niche markets to a greater or lesser extent. There is usually a solidarity within the niche which comes from shared experience and relationship to the experience. The tendency of individuals to build up skills in the experience means they can enhance their position as (co)consumers and increase their store of emotional energy (similar to Csikszentmihalyi's (2000) concept of 'flow'). The maintenance of boundaries around the practice which mark off participants who follow the ritual correctly, such as the sharp divisions introduced between different categories of tourists by backpackers and 'travellers'.

We can see the emergence of ritual practices and their embodiment in specific networks. This is not so much the emergence of a market per se, but more the emergence of a social practice which can later become a market. A key question is: who identifies, maintains and utilizes the niche? This is a system of co-creation in which distinct practices provide the basis for interaction between consumers and producers. What gives many specialist companies a competitive edge is an understanding of these practices. Practices are in competition with one another to attract adherents, and therefore the study of how people are recruited into and are persuaded to maintain and build practices can arguably help us understand far more about co-created tourism niches.

Understanding how niche markets function is important for regional development, since many strategies rely on developing specialisations that can appeal to niche markets and thus reduce competition. In tourism this is evident from the many regions using niche tourism products as a development strategy. Backpacker tourism as a means of boosting the local tourism economy, because it is argued that backpackers are willing to travel to less popular areas in search of new experiences (Hampton, 1998). The tendency for backpackers to travel 'off the beaten track' allows them to draw a boundary between the backpacking practice and other styles of tourism, providing more coherence for the ritual (Richards and Wilson, 2004). Suppliers of backpacker services, such as hostel owners, also become involved in the backpacker niche, and try to 'stay within the fence' of the niche by adopting lifestyles and attitudes that match those of the backpackers (Ateljevic \& Doorne, 2000). The development of backpacking communities incorporating producers and consumers has been shown to be particularly important in regional Australia, where agricultural economies have become dependent on backpackers as seasonal labour (Hanson \& Bell, 2007).

The development of similar niche communities can be seen in a range of different products, such as surf tourism (Hritz \& Franzidis, 2018), gastronomic tourism (Balderas-Cejudo, Patterson, I. \& Leeson, 2019) and religious heritage (Dinis \& Krakover, 2016). Such niches have clearly identifiable elements of ritual and seem to conform to Collins' (2004) general model of an interaction ritual. However, more research will be needed to confirm the extent to which the ritual processes in these niches are similar, or if different forms of interaction 
ritual can be identified. Understanding the mechanics of such rituals will enable companies and regions to make better informed decisions about future development options.

\section{Conclusions}

Traditional marketing-based approaches to niche markets have tended to focus on transactional views of the producers and consumers involved. Recent developments in marketing and social theory, however, have signalled the increasing importance of relationships in influencing the development of markets and the roles of producers and consumers. The use of interaction ritual theory provides an interesting additional dimension to this, with a potential explanatory mechanism for the coherence and persistence of the niche. Shared interests, or a focus of attention among participants in the niche helps to develop emotional energy and produces the internal goods necessary to sustain adherence to the practice. It also ensures that participants will move from one ritual to another, forming a chain of experiences that often remain in the initial niche. In the case of backpacker tourism, for example, this leads to a series of backpacking trips that generate emotional energy and the development of a travel career within the niche. Maintaining the ritual or niche on the part of both consumers and producers implies creating barriers to outsiders that mark off the niche as different from other consumption opportunities. In the case of backpacking this is reflected in the strong ethos of what it means to be a 'real' backpacker.

This new view of niches has important implications. Rather than viewing a niche as a simple slice of a market characterised by relative uniformity of demand, the niche can be seen as a social ritual that involves the co-creative actions of both consumers and producers. The fact that producers can also become part of the niche suggests that a community approach to the analysis of co-creation is fruitful (Boswijk, Thijssen and Peelen, 2005). Niches are produced and maintained by a community of consumers and producers with a shared focus of attention on a particular social practice, such as backpacking. Maintenance of the niche is therefore more complex than a simple exchange between producers and consumers, as it involves sustaining the community and its internal values through the mutual production of external goods. Members of the community therefore derive more than transactional satisfaction from their membership of the niche community.

\section{References}

Ateljevic, I., \& Doorne, S. (2000) 'Staying within the fence': Lifestyle entrepreneurship in tourism. Journal of Sustainable Tourism, 8(5), 37-51.

Balderas-Cejudo, A., Patterson, I., \& Leeson, G. W. (2019) Senior Foodies: A developing niche market in gastronomic tourism. International Journal of Gastronomy and Food Science, 16, 100152.

Bargeman, B., \& Richards, G. (2020) A new approach to understanding tourism practices. Annals of Tourism Research, 84, 102988.

Bellavance, G. (2009) Models of Omnivorous Cultural Consumption: New Directions in Research. Poetics 36, 189-216.

Boswijk, A., Thijssen, T. and Peelen, E. (2005) A new perspective on the Experience Economy. Meaningful Experiences. The European Centre for the Experience Economy, The Netherlands.

Bourdieu, P. (1984) Distinction: A social critique of the judgement of taste. Routledge: London. 
Campos, R., \& Sequeira, A. (2020) Urban art touristification: the case of Lisbon. Tourist Studies, 20(2), 182-202.

Castelfranchi, C., Falcone, R. \& Marzo, F. (2006) Being Trusted in a Social Network: Trust as Relational Capital. Trust Management. Lecture Notes in Computer Science, 3986, 1932.

Castells, M. (2008) Communication Power. Oxford University Press: Oxford.

Collins, C. (2004) Interaction Ritual Chains. Princeton University Press: Princeton.

Currie, R. R., Campbell-Trant, T., \& Seaton, S. (2011) Joining the in-crowd: symbols for backpacker identity. International Journal of Culture, Tourism and Hospitality Research. 5(1), 47-56.

Csikszentmihalyi, M. (2000) The contribution of flow to positive psychology. In Gillham, J. E. (Ed.), Laws of life symposia series. The science of optimism and hope: Research essays in honor of Martin E. P. Seligman. West Conshohocken, PA: Templeton Foundation Press, pp. 387-395.

Dalgic, T. \& Leeuw, M. (1994) Niche Marketing Revisited: Concept, Applications and Some European Cases. European Journal of Marketing, 28(4), 39-55.

Dinis, A., \& Krakover, S. (2016) Niche tourism in small peripheral towns: The case of Jewish heritage in Belmonte, Portugal. Tourism Planning \& Development, 13(3), 310-332.

European Commission (2010) Communication from the Commission on 'Regional Policy contributing to smart growth in Europe 2020' (COM(2010) 553 final). Brussels: European Commission.

Hampton, M. P. (1998) Backpacker tourism and economic development. Annals of tourism research, 25(3), 639-660.

Hanson, J., \& Bell, M. (2007) Harvest trails in Australia: Patterns of seasonal migration in the fruit and vegetable industry. Journal of Rural Studies, 23(1), 101-117.

Hritz, N., \& Franzidis, A. F. (2018) Exploring the economic significance of the surf tourism market by experience level. Journal of Destination marketing \& management, 7, 164-169.

Jarvis, J. \& Peel, V. (2010) Flashpacking in Fiji: Reframing the 'Global Nomad' in a Developing Destination. In Kevin Hannam and Anya Diekmann (eds) Beyond Backpacker Tourism. Channel View: Clevedon, pp. 21-39.

Maclntyre, A. (2007) After Virtue: A Study in Moral Theory. London: Duckworth, $3^{\text {rd }}$ edition. Lim, C. C., \& Bendle, L. J. (2012) Arts tourism in Seoul: tourist-orientated performing arts as a sustainable niche market. Journal of Sustainable Tourism, 20(5), 667-682.

Michael, E. J. (2003) Tourism micro-clusters. Tourism Economics, 9(2), 133-145.

Newland, K., \& Taylor, C. (2010) Heritage tourism and nostalgia trade: a diaspora niche in the development landscape. Washington, DC: Migration Policy Institute.

Noy, C. (2004) THIS TRIP REALLY CHANGED ME: Backpackers' Narratives of SelfChange. Annals of Tourism Research 31, 78-102.

Novelli, M. (2005) Niche Tourism: Contemporary issues, trends and cases. Oxford: Butterworth-Heinemann.

Pearce, P.L. (2007) Sustainability research and backpacker studies: Intersections and mutual insights. In Hannam, K., \& Ateljevic, I. (Eds.), Backpacker Tourism-Concepts and Profiles. Bristol: Channel View Publications, pp. 38-53. 
Peters, M., Frehse, J. \& Buhalis, D. (2009) The importance of lifestyle entrepreneurship: A conceptual study of the tourism industry. Pasos 7, 393-405.

Richards, G. (2014). Imagineering events as interaction ritual chains. In Richards, G., Mein, K. and Marques, L. (Eds) Event Design: Social perspectives and practices, London: Routledge, pp. 30-40.

Richards, G. (2015) The new global nomads: Youth travel in a globalizing world. Tourism Recreation Research, 40(3), 340-352.

Richards, G., \& Wilson, J. (Eds.) (2004). The Global Nomad: Backpacker travel in theory and practice. Channel View Publications.

Sert, A. N. (2017) Niche marketing and tourism. Journal of Business Management and Economic Research, 1(1), 14-25.

Simons, I. (2019) Events and online interaction: the construction of hybrid event communities. Leisure Studies, 38(2), 145-159.

Tassiopoulos, D., \& Haydam, N. (2008) Golf tourists in South Africa: A demand-side study of a niche market in sports tourism. Tourism Management, 29(5), 870-882.

Walder, B., Weiermair, K. and Sancho Pérez, A. (2006) Innovation and product development in tourism: creating sustainable competitive advantage. Erich Schmidt Verlag: Berlin.

Welk, P. (2004) The Beaten Track: Anti-Tourism as an Element of Backpacker Identity Construction. In Richards, G. and Wilson, J. (eds) The Global Nomad: Backpacker travel in theory and practice. Channel View: Clevedon.

Zhang, J., Tucker, H., Morrison, A. M., \& Wu, B. (2017) Becoming a backpacker in China: A grounded theory approach to identity construction of backpackers. Annals of Tourism Research, 64, 114-125.

\section{About the authors}

Greg Richards is Professor of Placemaking and Events at Breda University of Applied Sciences and Professor of Leisure Studies at Tilburg University in the Netherlands. His research interests include the relationship between tourism, creativity and development, and the use of events as a development tool. He has also undertaken extensive research on backpacking and youth travel practices. 